\title{
BEYOND STRESS TESTING: MODELLING LIQUIDITY AND INTEREST RATE RISKS FOR (REAL) CORPORATE MEASURES
}

\author{
Filippo Antonio Dal Prà \\ Veneto Banca group \\ ALM and Liquidity Risk Department \\ Via Feltrina Sud 250 \\ I-31044 Montebelluna (TV) \\ Tel. +39-(0)423.283.649 - Fax. +39-(0)423.283.375 \\ Filippo.DalPra@venetobanca.it ${ }^{1}$ \\ Guido Max Mantovani \\ Ca' Foscari University \\ Department of Management \& Ca' Foscari Challenge School (Dean) \\ San Giobbe - Cannaregio 873 \\ I-30121 Venezia \\ Tel. +39-041.234.8727 - Fax. +39-041.234.8701 \\ g.mantovani@unive.it
}

\begin{abstract}
The financial crisis exploited the poorness of real liquidity risk perception in the banking system. The paper suggests a wiser uses of econometrics tools can be more effective in detecting banking risk in order to reduce bias in the decision processes. A methodology to better focus the real bank exposition to interest rate risk is proposed fixing several bugs related to the assessment of its connections with: (i) the credit risk embedded in loans; (ii) the concentration risk of assets and liabilities relating to specific customers; (iii) the volume risk, particularly for unexpected changes. The Veneto Banca experience and performance are used as gymnasium for a possible method development aiming to propose a standard for a more comprehensive corporate risk approach in banking, even for Regulators.
\end{abstract}

Keywords: Liquidity risk, ALM, corporate risk, risk premia

JEL Classifications: G21, E27, F47, D92

This release: November 2011

\footnotetext{
${ }^{1}$ Contacting Author. The Authors thank Veneto Banca Group for allowing the use of data inside the paper. Special thanks are to be given to Dr. Cristian Gazzola (Veneto Banca Group) for the support in model development and application, Dr. Elisa Bisconti (Teofilo Intato Foundation) for supporting the scientific modelling and literature research, Dr. Cristina Dal Prà for the revision job she did over the English version, Dr. Fabiola Emili and Dr. Federica Callegaro (Veneto Banca Group) for the kindly in extracting data and, last but not the least, Dr. Renato Merlo (Head of planning and management control department) for making this as possible.
} 


\section{Introduction}

Financial crisis clearly deployed the weakness of the global banking system but the academic community is still searching for an affordable explanation of its causes. Risk sources existing before the crisis cannot be clearly focused using traditional (i.e. widely used) risk-analysis tools adopted in the best western banking practice (i.e. bulk-so-unwise use of econometrics). Such hidden risks are the basic reason for both missing points, driving markets to overestimate the return-to-risk ratio of the banking industry and driving think-tanks to suggest the use of bulker and more complex technical solutions.

The liquidity risk seems to be one of the most missed point. Several assets were declared "toxic" while actually being simply "illiquid"; their returns were declared "fair" because compared to risk-levels supposing a "full marketability" at no costs; the equity constraints in the banking system were regulated aftermath. One of the mostly lost quest was concerned with the trade-off between the time horizon of investments and their liquidity. The longer is the first according to the preferred investors' habitat, the stronger is to be the equity constraint of the financial intermediaries supporting the investors: Franco Modigliani docet!

The corporate view of risk (in banking) is another absent-minded point. Financial intermediaries aren't a simple portfolio or elementary risks, based on a stable long term covariance matrix (usually because mean-reversion matters!). This being the case, their existence should immediately evaporate through unbundling arbitrages based on complete markets. Banking risk is corporate-body-mix of risks having flexible (i.e. difficult to model) relationships made up of stable covariance matrix in the managerial expected range of variability along with more complex relationships because crafted by managerial decisions. Thus, corporate reaction to risks matters, reducing the unbundling opportunity. Being driven by managerial decisions, the corporate reaction requires to be strongly supported by correct risk perception at corporate level. Bulky econometrics methods can drive unfair estimation of the corporate risk due to their inability to detect real relationships of specific risks in the corporate body (i.e. the corporate reaction).

The liquidity risks web into the banking corporate body is a typical example. The economic impact of changes in market short term interest rates cannot be completely modeled without considering both their impact over the investors' attitude to commit to a specific banking investment and their effect to the premia dimension of other risks, particularly the credit risk one.

In this paper we suggest a different approach aiming to demonstrate how the actual (i.e. corporate) use of the models can increase their efficacy more than their bulkiness. The paper is composed as follows: Section 1 presents the referring theoretical framework for modeling the liquidity risk in banking economics and its 
inner methodological quests for corporate implementation; Section 2 reports the inner results of a pilot project aiming to fit an affordable methodology for model implementation at corporate level jointly run by Veneto Banca Group and Ca' Foscari University inside the "Master in Strategic Innovation" executive program; Section 3 depicts the resulting figures from model application to the Veneto Banca's economics along with some insights to obtain the maximum increase in the organization reactivity of the bank through the corporate use of the model; Section 4 concludes with suggestions for a wider use of the methodology.

\section{Literature review and theoretical models.}

Interest rate risk exposure and liquidity constraints inside a bank may be analyzed by defining the nature of assets and liability items according to a specific standards. The liquidity constraint is related to assets and liabilities to which the bank is committed to rapidly convert them into cash. This being the case, such items are usually tracking the interest rate movements, either because they are formally indexed to market rates, either because their attitude to rapid cash conversion requires a continuously updated return. The inner liquidity risk for any financial intermediary is not the exogenous change in market rates but the mismatch between assets and liability standards: any gap could leverage the corporate margin changes against to market volatility.

Entrop, Wilkens and Zeisler (2009) strike out the importance of fixing standards to classify asset and liability nature for liquidity. They start from the idea that the interest rate risk is systematic and it may directly affect the stability of the financial system, and examine whether the framework proposed by the Basel Committee for the quantification of interest rate risk in banks is adequate. If the guidelines were to be too simplistic or inadequate, bank supervisors could misjudge the interest rate risk of banks and react inappropriately to external shocks. The Authors show that the estimate of the level of interest rate risk is strongly influenced by the parameters of Basel Committee which may lead to a misinterpretation of the level of risk which the bank is exposed if its structure is different from that envisaged by Basel. For this reason the Authors suggest that banks should use an internal (i.e. "customized") model to define the exposure to changes in interest rates. Lopez (2004) gets to a very similar conclusion by examining the standards for interest rate risk definition embedded in the previous Basel agreement. The principles strongly support the idea that banks' internal risk assessments should form the basis for supervisory oversight of their interest rate risk profiles. 
Thus, according to these authors the internal classification matters. The expression "at sight ordinary ${ }^{2}$ customers" usually means a mix of technical forms, both on liability and asset side of the banking balance sheet having at least two inner characteristics: (a) a fixed maturity, since they are characterized by having a contractual maturity formally exposed (at least for the single report) but against which there is a substantial persistence and stability of relations taken together; (b) an explicit rule for determining the rate, either in terms of periodicity of review, nor in terms of parameters of the target market. The most typical example are deposits and investments having a customer loyalty greater than the actual maturity of the contract. The average weight assume the deposits of total interest-bearing liabilities in the Italian banking system is on average $50 \%$.

The reported weight assumes that the demand items in the composition of the budget of a commercial bank and the reduced level of elasticity between the rates charged to customers and market rates, cause a significant interest rate risk in case of change of the latter, with a heavy impact on the income statement (and economic value). This risk is not always properly measured and only a few (big) banking groups are covering such a quest ${ }^{3}$. Dell'Ariccia and Marquez (2010) identify different sources of risk as important determinants of banks' corporate structures when expanding into new markets. Subsidiary-based corporate structures benefit from greater protection against economic risk because of affiliate-level limited liability, but are more exposed to the risk of capital expropriation than are branches. Thus, branch-based structures are preferred to subsidiary-based structures when expropriation risk is high relative to economic risk, and vice versa. Greater cross-country risk correlation and more accurate pricing of risk by investors reduce the differences between the two structures. Furthermore, a bank's corporate structure affects its risk taking and affiliate size. Even if the analyses abstracts from a number of real world considerations that may affect a bank's choice of corporate structure, they illustrates how banks can design their organizational structures to better cope with two primary sources of risk (political risk and credit risk). The predictions of the model for banks' organizational forms are consistent with the empirical literature. Moreover, the analysis has implications for the relative sizes of branches versus subsidiaries, and for the risk-taking incentives of the different structures.

Fraser, Madura and Weigand (2002) examine bank stocks' sensitivity to changes in interest rates and the factors affecting this sensitivity. They focus in whether the exposure of commercial banks to interest rate risk is conditioned on certain

\footnotetext{
2 In the present paper the words "at sight" mean budget items that make up the assets, bank overdrafts and subject to collection, for the liabilities, the current accounts and savings deposits. The indexed accounts included in this series as the bargaining power of the intermediary credit is small enough to take action to change the spread and/or parameter and/or the frequency of repricing.

${ }^{3}$ In Italy this kind of operation has been performed only by Banca Intesa and Unicredit.
} 
balance sheet and income statement ratios. They find out: (i) a significantly negative relation between bank stock returns and unanticipated changes in interest rates over a period of relatively unstable interest rates (1991-1996); (ii) that bank interest rate risk is invariant to bank size classification. Thus the evidence that variation in interest rate risk can be explained by readily observable bank characteristics is relevant to bank managers who want to manage their risk exposure, regulators who want to oversee changes in exposure and investors who revalue bank stocks in response to interest rate movements.

Wright, Houpt, Tlou and Hacker (1996) infer about factors that may be affecting the level of interest rate risk among commercial banks and estimate the general magnitude and significance of this risk. The results of the analysis suggest that the simple model used can be useful for broadly measuring the interest rate risk exposure of institutions that do not have unusual or complex asset characteristics. Interest rate risk does not currently appear to present a major risk to most commercial banks. Nevertheless, for individual institutions, interest rate risk must be carefully monitored and managed, especially by institutions with concentrations in riskier or less predictable positions. According to Duan, Sealey and Yan (1999) banks manage interest rate risk by choosing asset and liability portfolios in order to monitor changes in the value of target variables that result from changes in interest rates. The authors present a comparison of numerical models based on options and conventional ones. The results show that the two approaches can give very different values for exposure to interest rate risk, especially during periods with higher than average rate volatility and/or credit risk for banks with higher than average. Authors pay attention on the fact that it is not possible to say that one is always best.

Alessandri and Drehmann (2010) try to infer about a corporate view of risks including credit, market and liquidity risk, in that paper the authors derive an economic capital model which consistently integrates credit and interest rate risk in the banking book but it doesn't address the issue of what is the appropriate level of capital for a bank. They focus instead on the question of how this level of economic capital is influenced by interactions between credit and interest rate risk. The main result of the analysis is that simple capital exceeds integrated capital. In other words: a simple approach to aggregate credit risk and interest rate risk in the retail loan book doesn't lead to an underestimation of risk, compared to an approach that takes into account the interactions between the two sources of risk. The difference between the two depends on various features of the bank.

Trying to represent accurately in terms of risk and profitability for "non-maturity" items, econometric modelling should then recognize the two distinctive features: (a) the limited degree of indexing rates (especially for the collection), so we can process the products (collection) exposed to similar fixed-rate instruments; (b) the high persistence of aggregate thereby assimilating items analyzed in liabilities / assets medium to long term. In detail, the quantification of the impact of a shock to market rates on income and economic value can be made to articulate the research through the use of two econometric models: (i) those referred to rates, which describes the dynamics the interest rate on sight, and identifies a product 
indexing formula that ties the rate charged to customers at the market rate; (ii) those analysing the volumes particularly in terms of stock persistence.

The model for interest rate risk measurement requires first to identify a relationship pricing heuristics, and this is estimated by placing a link between the rates of demand items with market rates through an error-correcting econometric model ECM which is composed of two separate reports: long-term relationship (or equilibrium) and short-run relation (or dynamic).

The long-term relationship provides a measure of how changes in market rates $\Delta r m_{t}$ are reflected in changes in the rate of demand items and it is represented by the following formula:

$$
r^{*}=\alpha+\beta \cdot r m_{t}
$$

where the parameters are:

\begin{tabular}{|c|l|}
\hline$r^{*}$ & $\begin{array}{l}\text { bank rate long-run equilibrium consistent with the observed value of } \\
r m_{t}\end{array}$ \\
\hline$\alpha$ & spread on constant rate \\
\hline$\beta$ & long-term elasticity of bank rate in comparison with the market rate \\
\hline$r m_{t}$ & market rate reference observed at time $t$ (typically 1 month Euribor) \\
\hline
\end{tabular}

It should be noted that the bargaining power of banks ensure that changes in market interest rates do not reflect immediately and symmetrical changes in interest rates granted to customers. For this reason, the short-run relation of the model ECM is designed to measure the phenomenon of stickiness, highlighting the manner and timing of rate adjustment of demand items at the market rate of reference. It can be represented by the following formula:

$$
\Delta r_{t}=\theta \cdot\left(r_{t-1}-r_{t-1}^{*}\right)+\gamma^{+} \cdot\left|\Delta r m_{t}^{+}\right|-\gamma^{-} \cdot\left|\Delta r m_{t}^{-}\right|
$$

where:

\begin{tabular}{|c|l|}
\hline$\Delta r_{t}$ & variation in the rate applied by the bank between $t$ and $t-1$ \\
\hline$\theta$ & $\begin{array}{l}\text { rate of absorption(meanreverting)of bank rates to market } \\
\text { rates }\end{array}$ \\
\hline$r_{t-1}$ & the rate applied by the bank observed at time $t-1$ \\
\hline$r_{t-1}^{*}$ & long-run equilibrium base rate \\
\hline$\gamma^{+}, \gamma^{-}$ & $\begin{array}{l}\text { bank interest rate sensitivity, respectively, to the rise and } \\
\text { descent of the market }\end{array}$ \\
\hline$\Delta r m_{t}^{+}, \Delta r m_{t}^{-}$ & $\begin{array}{l}\text { respectively: changes in positive (negative) of the market rate } \\
\text { at time } t \text { compared to } t-1\end{array}$ \\
\hline
\end{tabular}

Taken together the long-term relationships and a formula describing the short index of "atypical", where the rate applied to the customer depends on the imbalance between the past values of the rate of the product and the market rate ( $\beta$ and $\theta$ parameters)and changes in current the market rate (positive or negative, represented by $\gamma^{+}$and $\gamma^{-}$).

Combining the two relations are obtained: 


$$
\Delta r_{t}=\theta \cdot\left(r_{t-1}-\alpha-\beta \cdot r m_{t-1}\right)+\gamma^{+} \cdot\left|\Delta r m_{t}^{+}\right|-\gamma^{-} \cdot\left|\Delta r m_{t}^{-}\right|
$$

Assuming then that before the shock on the market rate is in equilibrium, the instantaneous response of the rate parameters depends only on the $\gamma^{+}$and $\gamma^{-}$ parameters. If after the shock, the market rate does not undergo further changes, the speed of adjustment of the rate depends on the imbalance that has yet to be absorbed and on the $\theta$ parameter.

The model for volumes analysis should represent the maturity of demand items as realistic as possible, highlighting the high degree of persistence of aggregates. For this purpose we assume that the volumes do not remain constant on the holding period agreed, but design a progressive decline in a virtual amortization profile and transform so the amount of demand items placed in a portfolio at maturity. This profile is the result of a historical analysis of volumes, suitably smoothed through a filter statistics to grasp the historical trend from which to draw the décalage. In literature there are numerous treaties smoothing methods, such as the Hodrick-Prescott filter, Kalman, moving average, cubic spline ... In this work we applied the first one. In short, given a set of historical data $x_{t}$ that is supposed to be composed of a historical trend $\tau$ and of a cyclical component $c_{t}$ superimposed on the trend, the HP filter isolates the cyclical component, solving the following minimization problem:

$$
\min _{\left\{\tau_{t}\right\}_{t=1}^{T}}\left[\sum_{t=1}^{T}\left(y_{t}-\tau_{t}\right)^{2}+\lambda \sum_{t=2}^{T-1}\left(\left(\tau_{t+1}-\tau_{t}\right)-\left(\tau_{t}-\tau_{t-1}\right)\right)^{2}\right]
$$

where the penalty parameter ë is the smoothing parameter that allows to adjust the sensitivity of the trend to short-term fluctuations.

The analysis is carried out starting from the natural logarithm of unit volumes, as for each $t$. It is applied to the HP filter and we calculated the historical volatility of the logarithmic series around the trend and determinates the most stable component (so-called core deposits). In this way, from the statistical analysis of the volumes' persistence we identified two components: a stable (core) and a highly volatile(non-core). In logarithmic terms, the core component of unit volumes, $\hat{v}(T)$, is defined as follows:

Where :

$$
\hat{v}(T)=\tilde{v}(T)+\sigma\left(\widetilde{\varepsilon_{v}}\right) \cdot q_{(1-\alpha)}
$$

\begin{tabular}{|c|l|}
\hline$\tilde{v}(T)$ & $\begin{array}{l}\text { trend obtained by applying the volume Hodrick Prescott filter } \\
\text { to the natural logarithm }\end{array}$ \\
\hline$\sigma\left(\widetilde{\varepsilon_{v}}\right)$ & volatility around the trend \\
\hline$q_{(1-\alpha)}$ & $\begin{array}{l}\text { value of the standard normal distribution at a confidence level } \\
\text { equal to } \alpha \text { (Used the } 99 \text { th percentile) }\end{array}$ \\
\hline
\end{tabular}

Once the core component is identified, we detected the persistence profile and we determined a profile of likely minimum volumes ( $m p a$, minimum probable amount). Under a fixed confidence $\alpha$ level, the amount statistically certain to be present next month is obtained by the following equation:

$$
\operatorname{mpa}(T+h)=e^{\hat{v}(T)+\sigma\left(\widetilde{\varepsilon_{v}}\right) \cdot q_{(1-\alpha)} \cdot \sqrt{h}}
$$


where $h$ is the number of periods is defined on the repayment of virtual items on demand. Once Mpa is established, the "depreciation charge" (dc) of at sight items in each period $h$ is given by the following equation ${ }^{4}$ :

$$
d c(T+h)=\operatorname{mpa}(T+h-1)-m p a(T+h)
$$

As it is easy to guess, being the model for the analysis of volume data based on logarithmic data, the evolution of mpa volumes decreases exponentially over time with asymptotic nature and tends to zero. The remaining debt still exists existing at time $\mathrm{T}+\mathrm{H}$ is then redistributed evenly between $\mathrm{T}$ and $\mathrm{T}+\mathrm{H}$, redefining the mpa profile.

$$
d c^{*}(\mathrm{~T}+\mathrm{h})=\mathrm{dc}(\mathrm{T}+\mathrm{h})+\frac{1}{\mathrm{H}} \cdot e^{\hat{v}(T)+\sigma\left(\widetilde{\varepsilon_{v}}\right) \cdot q_{(1-\alpha)} \cdot \sqrt{\mathrm{H}}}
$$

Mpa* therefore becomes as follows:

$$
\operatorname{mpa}^{*}(T+h)=e^{\hat{v}(T)}-\sum_{i=1}^{h} d c^{*}(T+i)
$$

In terms of the unit volumes the core component is given by:

$$
\text { core }=e^{\hat{v}(T)}
$$

while the volatile component is obtained as the difference between the actual volume and the core component:

$$
\text { Nocore }=V(T)-\text { core }
$$

\section{Toward a new approach.}

The model currently applied by Veneto Banca Group (a medium size, fast growing Italian bank) to determinate the parameters of the ECM model and the volumes persistence is obtained through historical data provided by the Management Control. Customers are divided into three distinct groups:

- "wholesale" customers, that are classified by the Management Control as directional

- "Intra-group" customers, that are the relations with legal entities of the group;

- other customers, defined for simplicity "retail".

The first two customer types are not treated with econometric models for two reasons:

1. For "wholesale" customers: the average balance on cash accounts is so substantial that it is unrealistic to assume their place in a short time if the customer turns his savings to another bank.

${ }^{4}$ In this paper, the number of period (h) is assumed to be 120 (ten years). 
2. Intercompany relations are used for the natural functioning of society and they are settled by market rate.

So, being conservative, the balance on current accounts with these two types of customers are actually treated as sight items, both from the point of view of the rate adjustment and from the point of view of the term presence (it is assumed that rates are overnight). Instead, the relations with "retail" customers are subjected to the econometric estimations.

This methodology presents some limits. The main regards the "clustering" between "wholesale" and "retail" that is made by the business segment: this attribute is likely to change over time because of different trade policies. Each customer, in fact, may be changed from a segment to a different at any time without its behavior actually changes. The other limit points out in case of growth by external acquisition of a bank or branches. These two issues make it difficult to build a deep homogeneous time series over 32 months (32 monthly observations, which are data available from the Management Control). The historical depth recommended for the determination of the model is at least five years even if it leads to a good approximation already with 20 observations.

To overcome these problems and thereby increase the depth of time series and getting a more steady and objective outcomes, we have grouped the at sight forms of funding and lending according to the segment of economic activity (SAE). This attribute is stable over the time because it is not susceptible to commercial clustering. Furthermore, we thought to historicize the data for individual counterparties, so that, at the time of analysis, it is possible to reconstruct a consistent time series with the latest situation. In this way, in fact, we enucleated relations that at the reference date have the distinction of being intercompany even if they aren't in the old estimation thus solving the second problem. With the SAE, we decided to separate the technical forms of funding and lending in two sub-series, through the Basel III recommendations, assembling in two distinct categories (retail, wholesale). The econometric estimates conducted and described in the following sections confirm that this subdivision allows to identify clusters statistically different from each other and at the same homogeneous within them.

\subsection{Analysis of concentration risk}

The two main clusters obtained according to the specifications of the previous section are further analyzed to determine if they meet the model core assumptions of volumes persistence. This feature could be read through the concentration ratio. More funding/lending is concentrated, more it is difficult for the credit intermediary to be able to quickly replace the customer and then to 
have stable volumes onward. For this reason we calculated the Hirschman Herfindahl's concentration ratio. In Table 1 (third column), we report the results.

\begin{tabular}{|l|l|c|c|c|}
\hline Balance sheet side & \multicolumn{1}{|c|}{ Serie } & HH index & $\begin{array}{c}\text { Equivalent } \\
\text { number }\end{array}$ & $\begin{array}{c}\text { Customer } \\
\text { number }\end{array}$ \\
\hline Asset & Retail & 0.005450 & 183.46 & 48,546 \\
\hline Asset & Wholesale & 0.006372 & 156.95 & 33,852 \\
\hline Liability & Retail & 0.000145 & $6,878.26$ & 279,033 \\
\hline Liability & Wholesale & 0.043344 & 23.07 & 39,322 \\
\hline
\end{tabular}

Table 1: Hirschman - Herfindal index

All coefficients tend to zero, because the market quota of every single customer is little. So, it seems to be in a perfect market, without concentration. But, if we estimate an absolute concentration ratio, estimating for example the top 20 customer weight on the total, we reach to another conclusion (see table 2).

\begin{tabular}{|c|l|r|}
\hline Balance sheet side & \multicolumn{1}{|c|}{ Serie } & $\begin{array}{c}\text { Weight of top 20 } \\
\text { customer }\end{array}$ \\
\hline Asset & Retail & $25.601 \%$ \\
\hline Asset & Wholesale & $15.454 \%$ \\
\hline Liability & Retail & $3.265 \%$ \\
\hline Liability & Wholesale & $48.619 \%$ \\
\hline
\end{tabular}

Table 2: Concentration ratio

The difficulty of correctly interpreting the results of $\mathrm{HH}$ indicator and consequently the impossibility to convey a clear and simple message to decision makers impose to try to "normalize" the index, through the equivalent number $\mathrm{N}^{5}$. This facilitates the evaluation of the concentration degree.

The scientific literature doesn't give any indication about the optimal concentration ratio. For this reason, we want compare the above described indicators with the system's ones. We contact the Central Bank of Italy in order to obtain time series and benchmark indicators. Unfortunately the detail, with which information is collected, it is not enough to create the indexes in the same manner as we did and then make a comparison. In fact, in recent years, the data for at sight instrument are collected only by distinguishing between geographical areas and not by the sector of economic activity. In the absence of a systemic confrontation index, we decided to use the interview method to understand what the optimal concentration for the most senior executives is.

\footnotetext{
${ }^{5}$ This index $\mathrm{N}$, calculated as the reciprocal of the $\mathrm{HH}^{\prime}$ s value, expresses the number of customers of the same size necessary to produce the given value of $\mathrm{HH}$. The value for retail funding is 0.0001454 . Its reciprocal is then 6,876 and indicates that value is reached in the presence of 279,033 customers of the same size.
} 
The two pertinent questions were as follows: (1) In your opinion, how much should be the top twenty customers weight on the total to haven't funding concentration? (2) Considering that the concentration percentage influences the degree of capitalization, how much should the first twenty customers weigh on the total?

There wasn't any mathematically clear indication to nor the first nor the second question. The explanation is simple: an objective threshold can't be defined because it depends on the bank's size, on the context in which it operates and on the strategy it intends to pursue. Regarding the first, in theory the concentration degree should decrease when the size of the financial intermediary increases. In reality, however, as the bank is bigger as it has the ability to offer services to customers of larger size and then to be chosen as counterpart. Regarding the second point, approximately $50 \%$ of the Italian banking system bearing liabilities consists of demand deposits. In May $31^{\text {st }}$, Veneto Banca Group is at $42.5 \%$. The leaders, therefore, believe that it isn't worth replacing the funding of most important customers with other funding forms, usually more expensive.

In conclusion, the degree of current concentration doesn't arouse any concern to managers. For our purposes this answer is not useful because if the top-twentycustomer-concentration level is not perceived as alarming, the demand instruments may treat them as a core component. But since the first customers have a market share of $48.6 \%$, this conclusion seems in contrast with the prudence principle. In the absence of a benchmark, the determination of the threshold (above which the econometric model can't be applied because it is in contrast with the immediate-substitution principle) it has been set empirically. We establish that the weight of the first twenty customers shall not exceed $5 \%$ of the total technical form. The number of customers has been established according to the inquiries of rating agencies, which regularly require the top ten or twenty customers for their studies ${ }^{6}$.

The following tables outline for all items the thresholds, the total balance, customer number, and the top-twenty-customer weight ${ }^{7}$. Alongside this ratio the Gini coefficient ${ }^{8}$ has also been reported. As a result, with the criterion of the relative weight of the top twenty customers who at first glance would seem the result of a naif approach, the Gini index is on average less than or equal 0.003

\footnotetext{
${ }^{6}$ This means that our analysis is hardly influenced by this assumption.

${ }^{7}$ In the next paper we will illustrate that in Northern Italy the no-concentration threshold is higher than in Center and South. For example, if we analyze the retail series (liability side) we can demonstrate that in the North the richness is not concentrated, thanks to an homogeneous distribution of families wealth. Instead, in south regions, there are some concentrated areas. These results should mark that the bank capitalization depends on wealth distribution.

${ }^{8}$ We prefer this concentration index because It is the simplest communicable. In fact, it can take a value ranging from 0 to 1 (the case of a single client).
} 
(see the green rows). This level highlights the customers" "lack of concentration". This approach has been respected for all series analyzed and it has been tested both on the first point of the series that last one. It betrays a substantial stability over time of the threshold level at which discriminate against the concentration.

\begin{tabular}{|c|c|c|c|c|c|c|}
\hline & B/S side & Liability & & Series & Wholesale & \\
\hline $\begin{array}{l}\text { UPPER LIMIT } \\
\text { AMOUNT }\end{array}$ & $\begin{array}{l}\text { STOCK } \\
(€ / \text { mil. })\end{array}$ & $\begin{array}{c}\text { CUSTOMERS } \\
\text { (number) }\end{array}$ & $\begin{array}{c}\text { AVERAGE } \\
(€)\end{array}$ & $\begin{array}{c}\text { Top 20 } \\
\text { customer } \\
\text { (stock) }\end{array}$ & $\begin{array}{c}\text { Top 20 } \\
\text { customer } \\
\text { (w eight \%) }\end{array}$ & $\begin{array}{c}\text { GINI } \\
\text { COEFFICIENT }\end{array}$ \\
\hline$<=5.2 \mathrm{~m}$ il. & $1,934.11$ & 40,646 & $47,584.26$ & 92.98 & $4.81 \%$ & $0.26 \%$ \\
\hline$<=10$ mil. & $2,276.97$ & 40,697 & $55,949.33$ & 164.02 & $7.20 \%$ & $0.43 \%$ \\
\hline$<=20$ mil. & $2,803.4$ & 40,735 & $68,820.42$ & 323.48 & $11.54 \%$ & $0.70 \%$ \\
\hline$<=40$ mil. & $3,294.9$ & 40,752 & $80,852.47$ & 550.13 & $16.70 \%$ & $1.21 \%$ \\
\hline \multirow[t]{2}{*}{ none } & $6,207.01$ & 40,771 & $152,240.81$ & $2,952.08$ & $47.56 \%$ & $18.27 \%$ \\
\hline & B/S side & Liability & & Series & Retail & \\
\hline $\begin{array}{l}\text { UPPER LIMIT } \\
\text { AMOUNT }\end{array}$ & $\begin{array}{c}\text { STOCK } \\
(€ / \text { mil. })\end{array}$ & $\begin{array}{c}\text { CUSTOMERS } \\
\text { (number) }\end{array}$ & $\begin{array}{c}\text { AVERAGE } \\
(€)\end{array}$ & $\begin{array}{c}\text { Top 20 } \\
\text { customer } \\
\text { (stock) }\end{array}$ & $\begin{array}{c}\text { Top 20 } \\
\text { customer } \\
\text { (w eight \%) }\end{array}$ & $\begin{array}{c}\text { GINI } \\
\text { COEFFICIENT }\end{array}$ \\
\hline$<=0.5$ mil. & $3,083.45$ & 277,070 & $11,128.78$ & 9.80 & $0.32 \%$ & $0.02 \%$ \\
\hline$<=1.5$ mil. & $3,275.92$ & 277,325 & $11,812.57$ & 26.14 & $0.80 \%$ & $0.05 \%$ \\
\hline \multirow[t]{2}{*}{ none } & $3,440.78$ & 277,378 & $12,404.66$ & 106.10 & $3.08 \%$ & $0.77 \%$ \\
\hline & B/S side & Asset & & Series & Wholesale & \\
\hline $\begin{array}{l}\text { UPPER LIMIT } \\
\text { AMOUNT }\end{array}$ & $\begin{array}{l}\text { STOCK } \\
(€ / \mathrm{mil} .)\end{array}$ & $\begin{array}{c}\text { CUSTOMERS } \\
\text { (number) }\end{array}$ & $\begin{array}{c}\text { AVERAGE } \\
(€)\end{array}$ & $\begin{array}{c}\text { Top 20 } \\
\text { customer } \\
\text { (stock) }\end{array}$ & $\begin{array}{c}\text { Top 20 } \\
\text { customer } \\
\text { (w eight \%) }\end{array}$ & $\begin{array}{c}\text { GINI } \\
\text { COEFFICIENT }\end{array}$ \\
\hline$<=12$ mil. & $3,905.92$ & 34,074 & $114,630.38$ & 194.91 & $4.99 \%$ & $0.30 \%$ \\
\hline \multirow[t]{2}{*}{ none } & $4,628.18$ & 34,091 & $135,759.60$ & 756.80 & $16.35 \%$ & $7.33 \%$ \\
\hline & B/S side & Asset & & Series & Retail & \\
\hline $\begin{array}{l}\text { UPPER LIMIT } \\
\text { AMOUNT }\end{array}$ & $\begin{array}{l}\text { STOCK } \\
(€ / \text { mil. })\end{array}$ & $\begin{array}{c}\text { CUSTOMERS } \\
\text { (number) }\end{array}$ & $\begin{array}{c}\text { AVERAGE } \\
(€)\end{array}$ & $\begin{array}{c}\text { Top 20 } \\
\text { customer } \\
\text { (stock) }\end{array}$ & $\begin{array}{c}\text { Top 20 } \\
\text { customer } \\
\text { (w eight \%) }\end{array}$ & $\begin{array}{c}\text { GINI } \\
\text { COEFFICIENT }\end{array}$ \\
\hline$<=0.85$ mil. & 319.90 & 50,238 & $6,367.69$ & 15.45 & $4.83 \%$ & $0.26 \%$ \\
\hline$<=0.89$ mil. & 323.40 & 50,242 & $6,436.88$ & 16.11 & $4.98 \%$ & $0.27 \%$ \\
\hline none & 638.56 & 50,323 & $12,689.17$ & 206.51 & $32.34 \%$ & $9.98 \%$ \\
\hline
\end{tabular}

\subsection{The Ecm model}

On the basis of the above illustrated methodology, we estimate the ECM model's parameters for every single series. We run the regression following the full model (one stadium approach) and its decomposition in the long/short period relation (two stadium model). In the next table, we report the regression results $\left(R^{2}\right)$. Since models are esteemed with data paucity (due to the short historical depth), we prefer the two stadium model because it is able to gather better the variability. Probably, with more observations, it is just sufficient the one stadium model. 


\begin{tabular}{|lcc|} 
Series & Full model & $\begin{array}{c}\text { Two stadium } \\
\text { model }\end{array}$ \\
\hline Asset side - retail & 0.5184 & 0.5462 \\
\hline Asset side - wholesale & 0.6132 & 0.6386 \\
\hline Liability side - retail & 0.8476 & 0.8697 \\
\hline Liability side - wholesale & 0.9435 & 0.9664 \\
\hline
\end{tabular}

Thanks to a careful analysis, we also define a logical work-flow for the model's application. First of all, the parameters' meaningfulness is based on a probability value equal to $5 \%$ ( $p$-value). Under this percentage we reject the null normality hypothesis. Analyzing the long term relation, it could happen that the parameter $\alpha$ or the $\beta$ are not acceptable. If it should happen at first one, we do not discover some theoretical limits, as it represents the intercept value, or in economic terms, it is equivalent to the mark-up when $\beta$ is 1 . Even if not significant, the $\alpha$ parameter has to be forced to the minimum rate recognized to the customer. Different reasoning for the $\beta$. If it should be negative or not significant the linear interpolation has no sense ${ }^{9}$. Only in one of our analysis, we found a case of insignificant $\beta$. To get round this problem, we investigated the events happened in that society. Specifically, some massive manoeuvres were make to avoid a customer hemorrhage. Calculating the regression from the last manouvre date, the $\beta$ became significant.

About the short period relation, we consider that the bank rates' sensitivity to the market rate changes must respect the following constrains, due to the bank's bargaining power:

\begin{tabular}{|ll|}
\hline Item & Constrain \\
\hline Assets item & $\gamma^{+} \geq \gamma^{-}$ \\
\hline Liability item & $\gamma^{+} \leq \gamma^{-}$ \\
\hline
\end{tabular}

In other words, if we are analyzing the series "assets retail" and the parameter $\gamma^{-}$ turned out not significant, the dynamic relation would become:

$$
\Delta r_{t}=\theta \cdot\left(r_{t-1}-r_{t-1}^{*}\right)+\gamma^{+} \cdot\left|\Delta r m_{t}^{+}\right|
$$

On the other hand, if the parameter $\gamma^{+}$turns out not significant while $\gamma^{-}$is acceptable, the used equation become:

$$
\Delta r_{t}=\theta \cdot\left(r_{t-1}-r_{t-1}^{*}\right)+\gamma^{+} \cdot\left|\Delta r m_{t}^{+}\right|-\gamma^{-} \cdot\left|\Delta r m_{t}^{-}\right|, \text {where } \gamma^{+}=\gamma^{-}
$$

Of course, we should think on the contrary when we analyze the liability series.

The results of the estimation must then be compared between system benchmarks and between asset and liability parameters. In Italy, the $\beta$ on the savings deposits is included between 0.3 and 0.4 (with an $R^{2}$ index at least to $60 \%-70 \%$; the volumes core percentage is between $80 \%$ and $85 \%$ ); in the asset

\footnotetext{
${ }^{9}$ We have to use linear regression because of software constraints. Otherwise we could not calculate the impact on earnings and on value because of changing in rates.
} 
side it should be included between 0.6 and $0.85\left(R^{2}\right.$ near to $50 \%$ and core percentage should be between $75 \%$ and $80 \%$.) Other considerations should be place on the parameters' values (asset vs. liability instruments) and their impact on the risk measures. In particular, the parameter $\beta$ has big influence on the asset sensitivity (lower on the liability's one). The last parameter $(\theta)$ has importance in the short period and therefore it has a greater influence on earnings analysis.

We also tried to consider the operating risk impact of the management time decision, delaying the series to a period (one month) and seeing if the model is more consistent. It turns out the graph below, in which we can clearly reject the hypothesis of autoregression in the equilibrium relation. That is confirmed by the statistical test Augmented Dickey Fuller (ADF) and by the $R^{2}$ index (respectively equal to 0.8518 for the ECM model - yellow line - and 0.2398 for the model $\mathrm{ECM}^{* *}$ which is the delayed one).

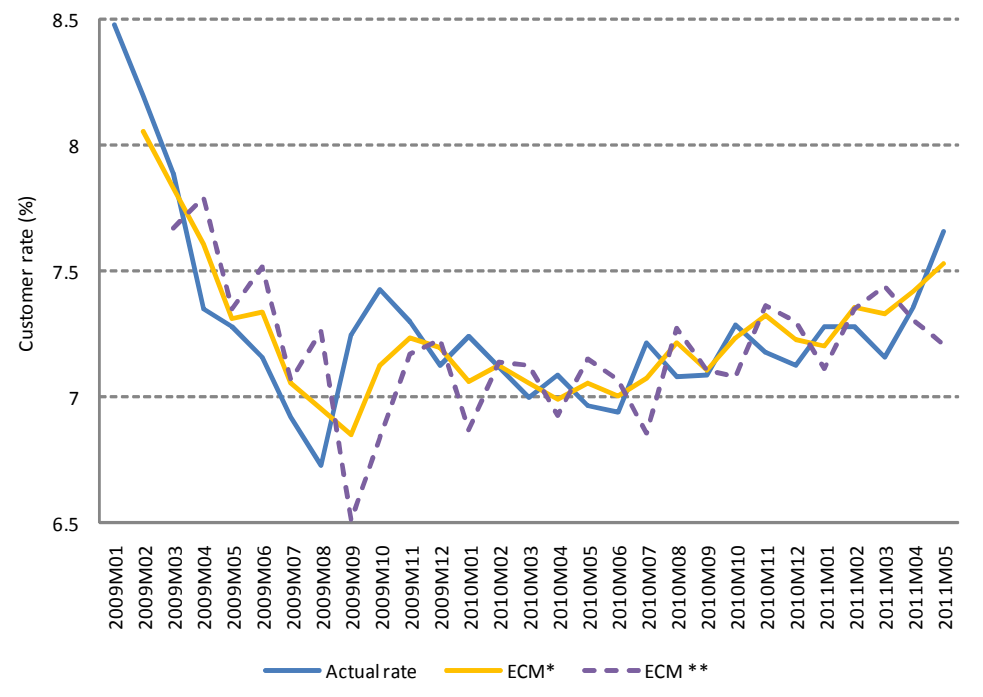

Figure 1: ECM model's consistance - retail asset side series

Further investigations are executed on each series to verify if clusters are statistically homogeneous and differentiated between them. Afterwards we illustrate reasonings on the retail and wholesale data.

\begin{tabular}{|lc|}
\hline Distribution & Values $(€)$ \\
\hline Mean & $12,316.99$ \\
Standard deviation & $77,477.25$ \\
Median & $50,000.00$ \\
Mode (range) & $0-10,000 €$ \\
95th percentile & $1,500 \mathrm{k}$ \\
99th percentile & $10,000 \mathrm{k}$ \\
Cash account's total amount & $3,436 \mathrm{~m}$ \\
\hline
\end{tabular}

Figure 2: Statistical distribution of retail's savings account 
As regards the first cluster an anomalous behavior seems to be visible (figure 3). It suggests the presence of two distinct phenomena. They could be explained through two different distributions, one normal and a uniform. Therefore we calculated the average and the standard deviation and we subdivided the series in two subseries: the first, which the threshold level is determined adding the standard deviation to the average; the second, consider all the customers with the settlement superior than level, but lower than 500,000 Euro (statistics are explained in fig. 2). It turns out that the behavior of the two series is perfectly identical from the distributive point of view and therefore we decide not to divide the series. However there is also the anomaly to justify. But, if we insert the time value, it is explained by a massive manoeuvre (please for widenings, see subsection 3)

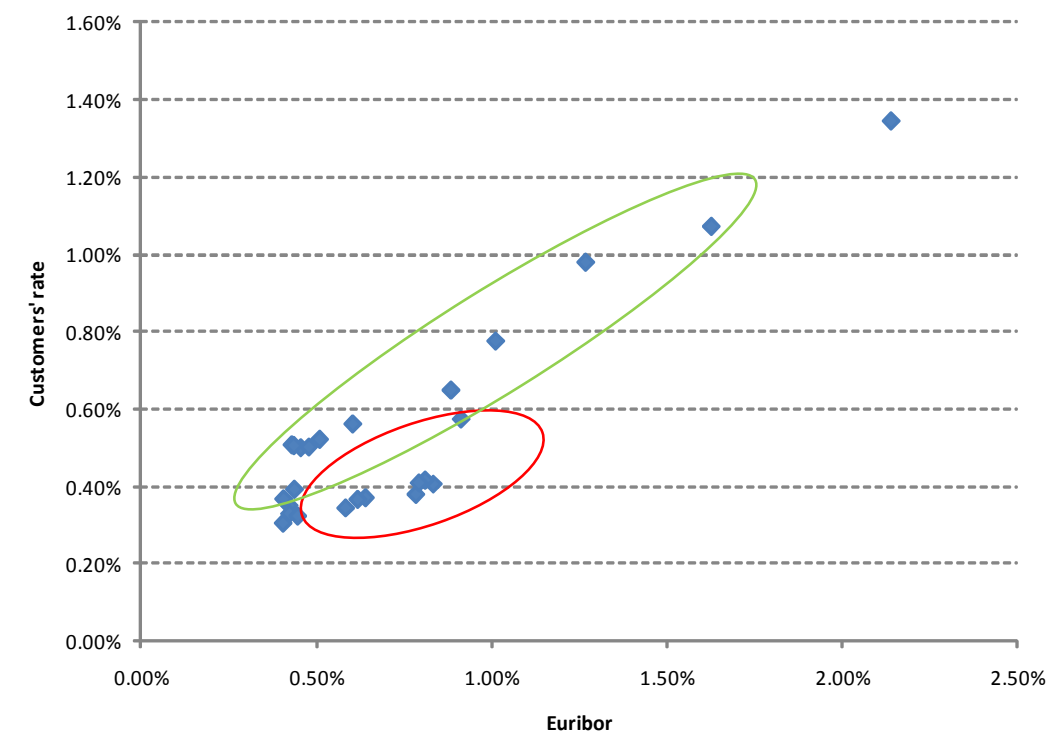

Figure 3: Correlation between Euribor and Customers' rate (upper limit: 500,000 €) 


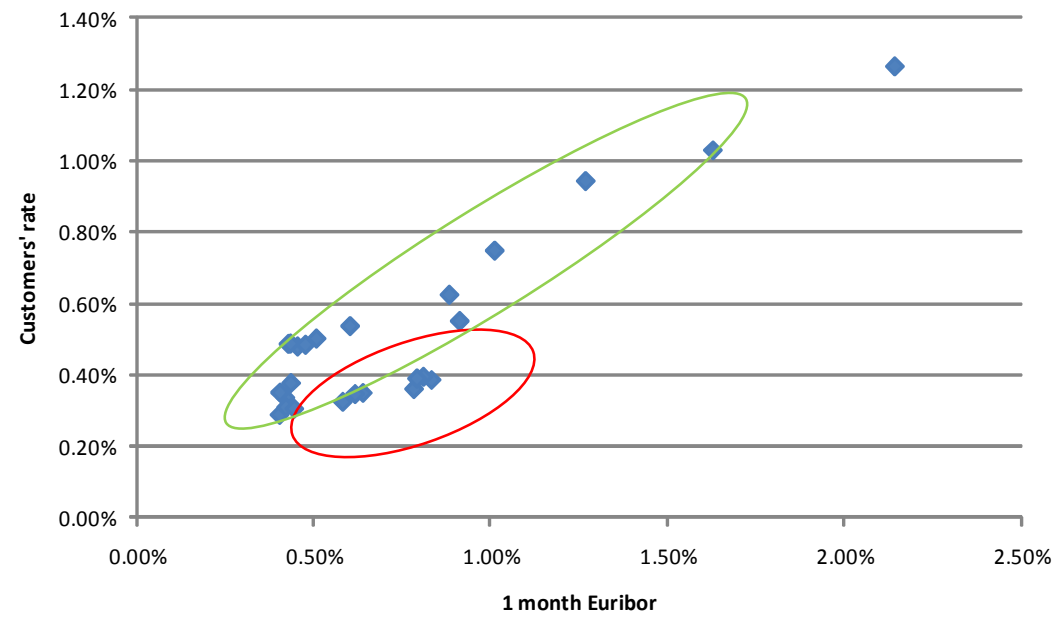

Figure 4: Correlation between Euribor and Customers' rate (upper limit: 90,000 €)

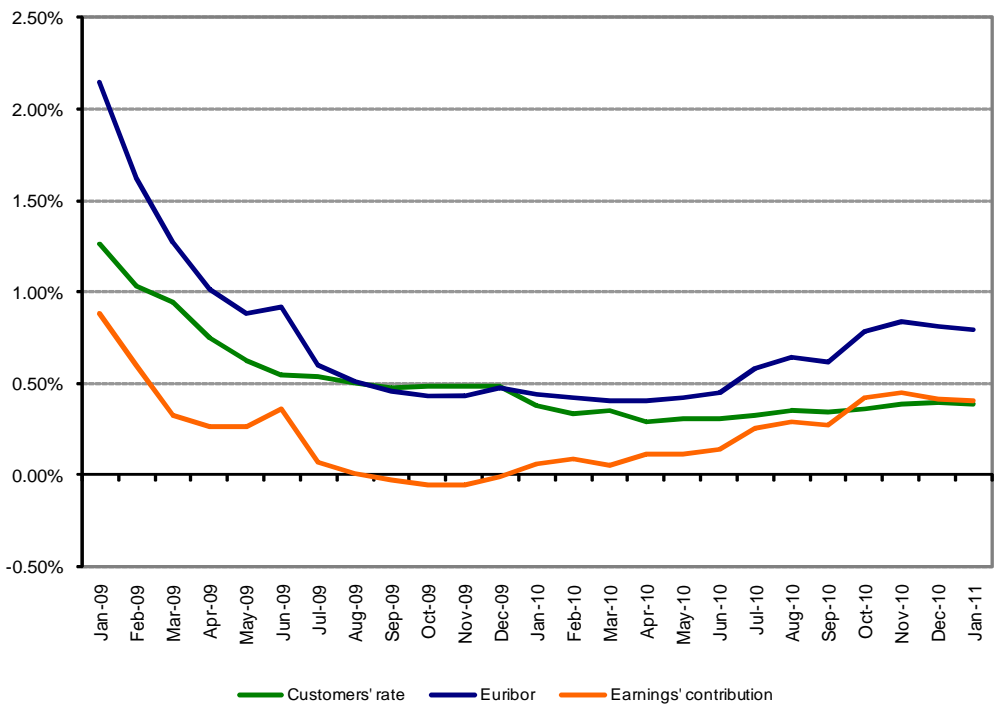

Figure 5: Rates' time series - retail (upper limit 90,000 €) 


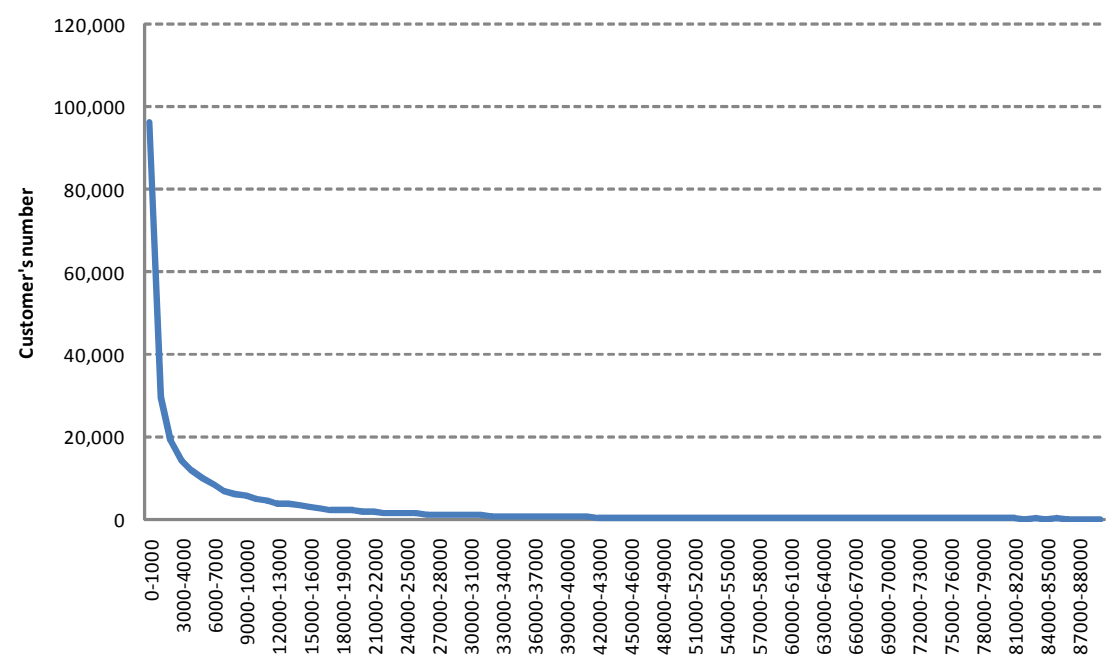

Figure 6: Customers' saving account distribution up to $90,000 €(1 \mathrm{k} €$ range)

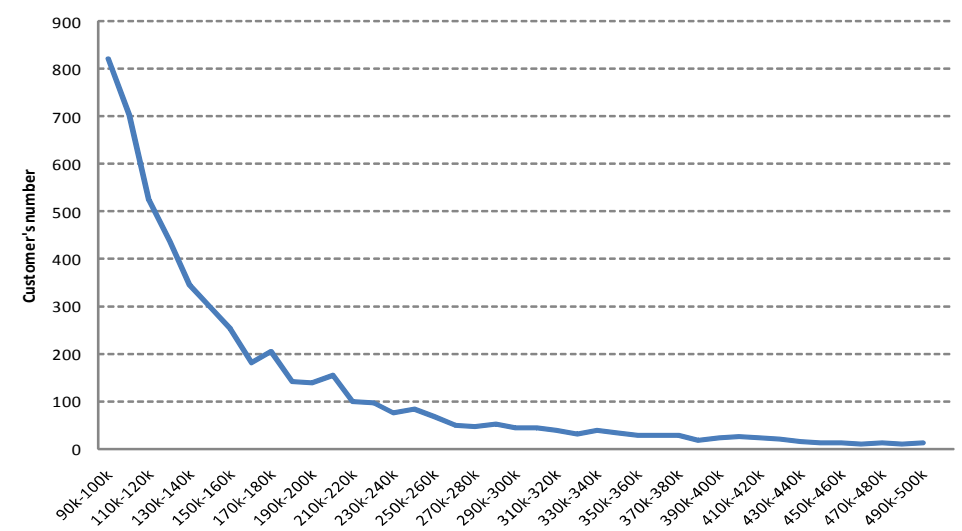

Figure 7: Customers' saving account distribution from 90,000 to $500,000 €(10 \mathrm{k} €$ range)

Concerning the asset-side cash accounts, we may consider that when the customer size increases, rates relationship raises. That could be inferred by the some graphs comparison (fig. 8,9,10), in which the correlation of the market rates with those paid from the customers moves up according to the increasing of the cash account middle settlement. Also in this case, we also tried to subdivide the series with settlements up to 7.5 million in three under series: the first with a top amount equal to 1.5 million; the second, between 1.5 million and 7.5 and the last one with maximum amount till 7.5. For each of them we calculate the long period relation with the aim to demonstrate that both the parameter $\alpha$ and $\beta$ are different. If they diverge we have to split the series in two subseries. Again, we observe that the customer's behavior in each of the two series is homogeneous: the difference is only on the intercept's value. Note the value of $\alpha$ parameter that is greater than the Italian market risk premia (about the 4\%) for the series with settlement lower than 1.5 million (fig. 9). 


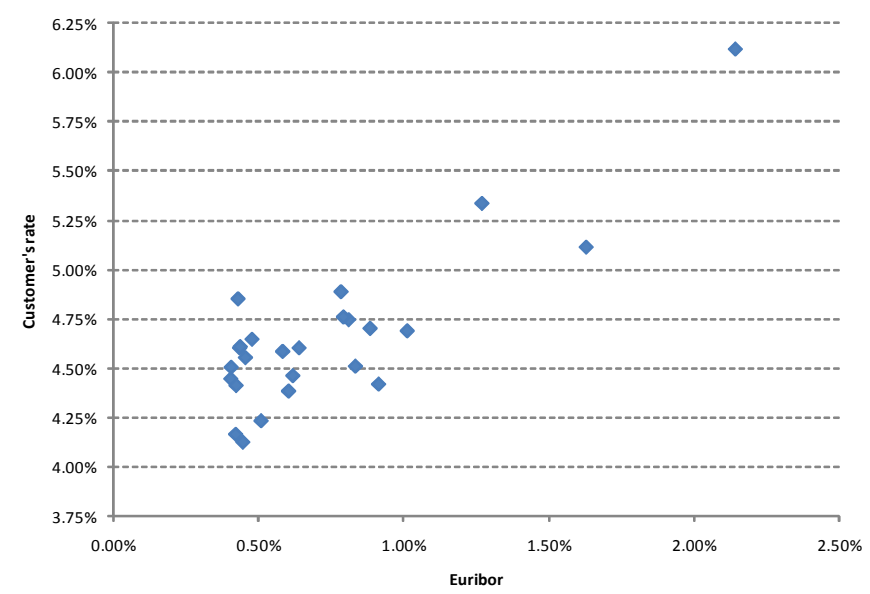

Figure 8: Correlation between Euribor and wholesale customer's rates (up to $7.5 \mathrm{~m} €$ ) - asset side

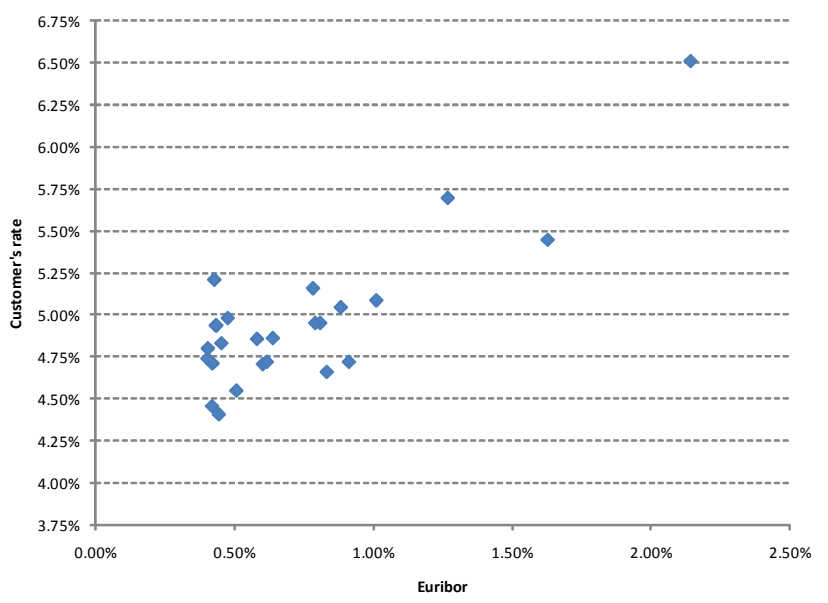

Figure 9: Correlation between Euribor and wholesale customer's rates (up to $1.5 \mathrm{~m} €$ ) - asset side

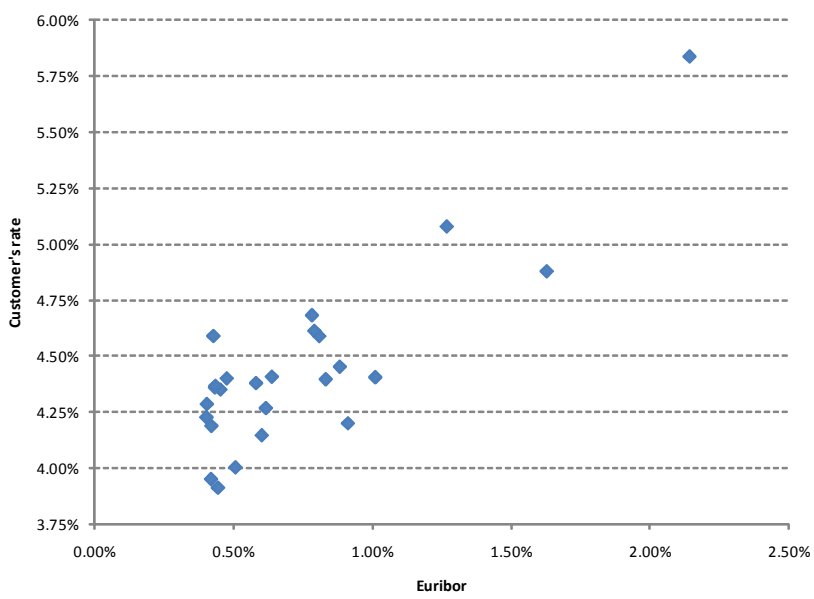

Figure 10. Correlation between Euribor and wholesale customer's rates (from 1.5m to $7.5 \mathrm{~m} €$ ) asset side 


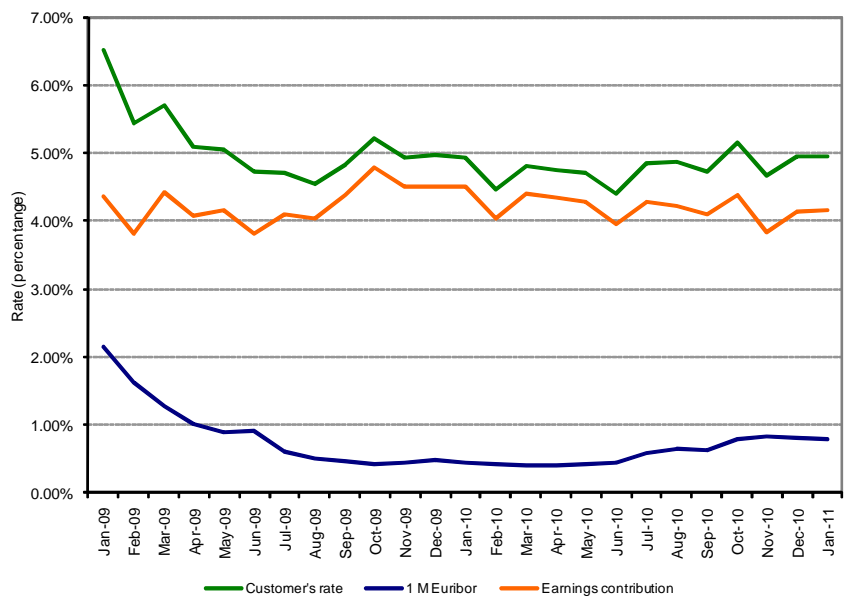

Figure 11: Rates' time series - Wholesale (up to 7.5k)

\section{The Veneto Banca experience}

The Veneto Banca experience best explains the benefits arising from adoption of the above methodology. In the specific case, analyses were conducts both at level of the total series and level of the not concentrated series (see the below table). From them we can draw numerous reflections. Firstly, we can notice the concentration effect on the ECM model's parameters (just the equilibrium relation). In this case, we have to verify if parameters are influenced by the concentration level. If they are, it means that it influences the research result. This case happens only for wholesale liabilities: however, it is justified by huge volume in game respect to retail ones.

\begin{tabular}{|c|c|c|c|c|c|}
\hline & Series & Upper limit* & Alfa & Beta & $\mathrm{R}^{2}$ \\
\hline \multirow{5}{*}{$\begin{array}{l}\frac{y}{0} \\
\frac{y}{y} \\
\frac{y}{c}\end{array}$} & Retail & none & $5.34 \%$ & 0.8654 & 0.5705 \\
\hline & & 890,000 & $6.68 \%$ & 0.7822 & 0.7518 \\
\hline & Wholesale & none & $3.62 \%$ & 0.8662 & 0.8419 \\
\hline & & $12,000,000$ & $4.07 \%$ & 0.8833 & 0.8143 \\
\hline & Total (Asset) & none & $3.79 \%$ & 0.8618 & 0.8242 \\
\hline \multirow{5}{*}{$\begin{array}{l}\frac{0}{0} \\
\frac{0}{n} \\
\frac{3}{\frac{2}{2}} \\
\frac{0}{10}\end{array}$} & Retail & none & $0.13 \%$ & 0.5525 & 0.7273 \\
\hline & & none & $0.13 \%$ & 0.5525 & 0.7273 \\
\hline & Wholesale & none & $0.48 \%$ & 1.1837 & 0.9564 \\
\hline & & $5,200,000$ & $0.14 \%$ & 0.9668 & 0.9027 \\
\hline & Total (Liability) & none & $0.48 \%$ & 1.1837 & 0.9564 \\
\hline
\end{tabular}

Analyzing the asset-side retail series (fig. 12) we have noticed that in specific historical moments the customer rates increases when market rate decrease. This 
seems in contradiction with what the macroeconomic model establishes.

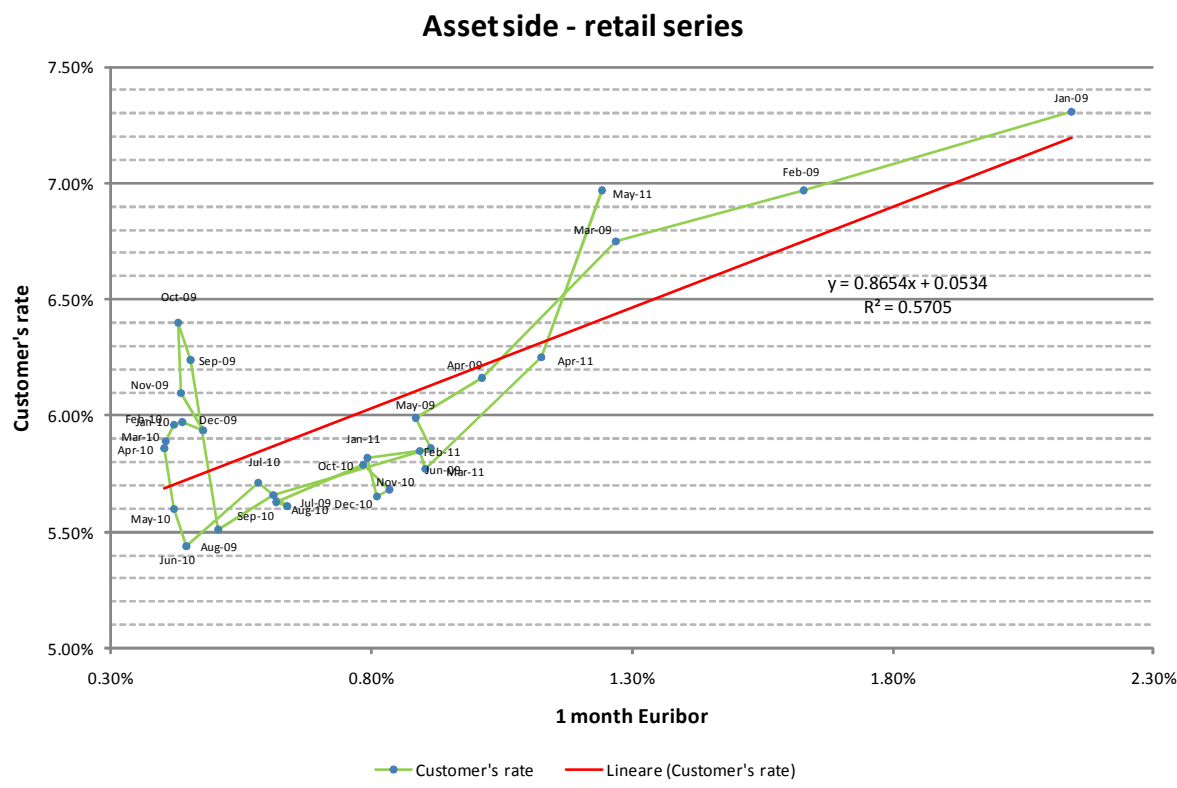

Upper limit: none

Figure 12: Correlation between Euribor and retail customer's rate (Upper limit: none)

For example, we go into more depth on the period between August and September 2009. Against 5 basis point contraction of one month euribor, the customer rate increases by almost 52 bps. Such jump is due the application of massive manoeuvres, that was reabsorbed in about 8 months. Between January 2009 and May 2011 happened four manoeuvres, two during the rates rising phase (June 2010, July 2010) and two in decrease phases (April 2009 and August 2009). From the graph 12 we can evict that the only one that truly had some effect was the August one, while other 3 were reabsorbed quicklier (two months at the most). We wonder about their real usefulness. In any case, the realization of the manoeuvres affects the result of the ECM. 


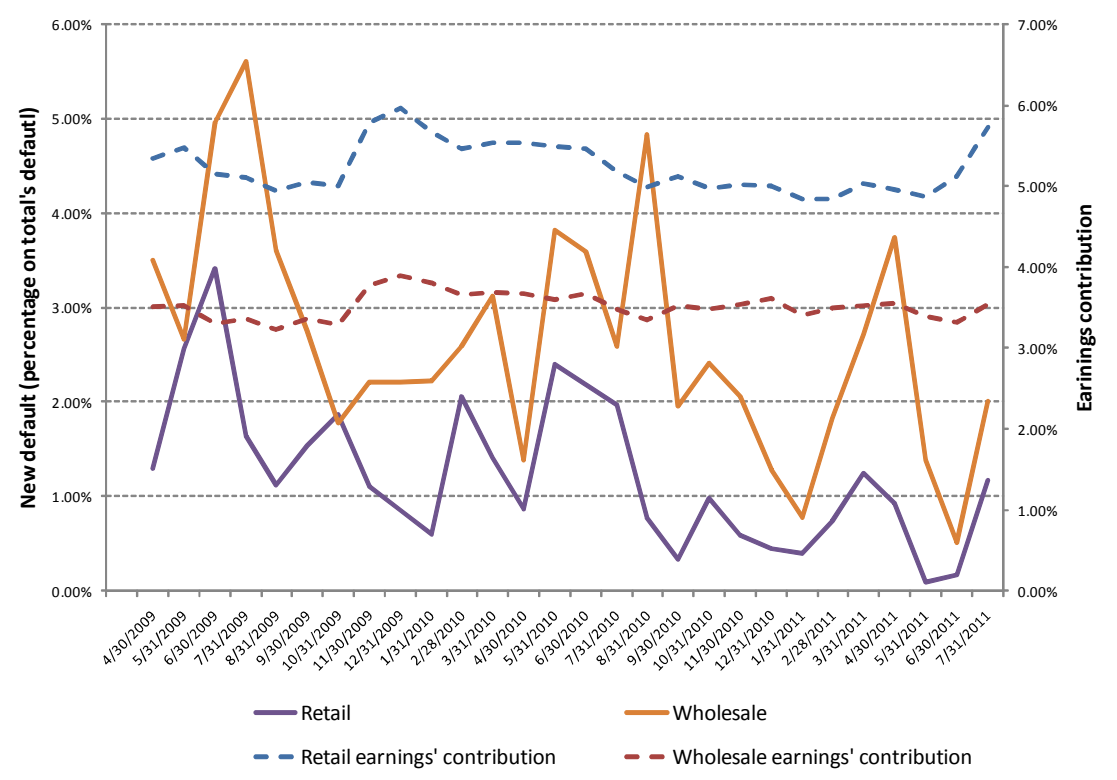

Figure 13: Relation between Earnings' cash account contribution and new default

To eliminate this distortive effect, we reflect on manouvres' guidelines. One of them could be attributable to the worsening of the customer credit spread. Unfortunately, this hypothesis is not verifiable, as the office responsible for credit monitoring does not monitor the phenomenon for single customer. As proxy, we could consider the new delinquent trend. If it increases in the incriminated period, would mean that the increase of the customer's rates due to the manoeuvre effect is originated by the credit spread and therefore is not explicable with interest rate risk but with credit ones. As consequence, for the ECM determination, we must purify the series from this phenomenon. This would allow a greater model trustworthiness on the future forecasts. This hypothesis opens two problems:

1. the new default dynamics could follow the customer rates after a certain time;

2. the relation between the interest rate risk and the credit one does not consider the risk aversion.

Therefore if the default and the asset/liability rates increase at the same time, the risk remuneration increases due to greater risk appetite (in line with the RAROC theory. As we can see in fig. 16, there is no relation between new default dynamics and cash account income. So, it should be important to advise the commercial department of this issue.

Concerning the retail-liability series, we can notice that the graph line depicts a lengthened $\mathrm{C}$. The differential between the top side and the lower summarizes 
the risk premia that the bank was able to obtain in two years. In fact between May 2009 and May 2011 the rate paid to customers is lower of almost 46 basis point. It would be interesting to investigate about the event that produced the turning point. It could be due to a missed bond emission, to a new company policy or to the turning around to another funding form. Considering these motivations, in additions to the written-above about the credit risk, we can conclude the model ECM is unsuited to forecast because it considers only one of many complex and articulate phenomenon.

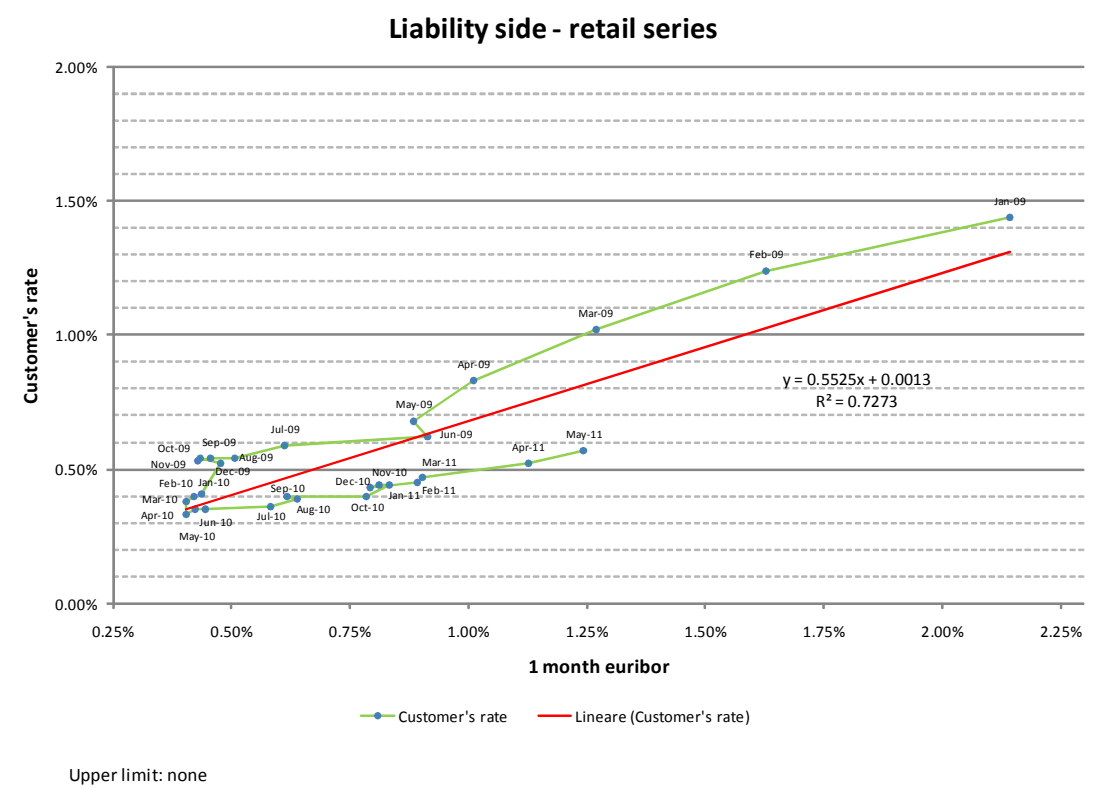

Figure 14: Correlation between Euribor and retail customer's rate (Upper limit: none)

Would be interesting verifying the existence of a positive correlation between the attribute "be partner" and the rate applied the customer. If confirmed, it means that we have created a synthetic saving share because the shareholder obtains a greater yield in cash accounts. But, if we can't confirm this hypothesis, the liability-side $\beta$ would be more worrisome, being superior to the system average. Moreover, due to the considerable concentration level, it would be opportune to move the liquidity risk on the market, inviting top customers to buy our bonds on the market or preference shares (with a yield equal to the no-preference-share plus one little percentage that is littler then cash account rate). This way would protect the bank both from the liquidity risk and the interest rate one, allowing a greater level and stability of the financial-margin interest.

Comparing the liability-side $\beta$ of wholesale customers with the asset-side one we can infer that this last one finances the liability concentration; covering the extra yield recognized to bigger customers. Would be useful verifying if these customers are shareholders. If so, the remuneration (1.18 times the euribor rate) is 
acceptable and therefore the $\beta$ value is an appearance characteristic of the bank's business model.

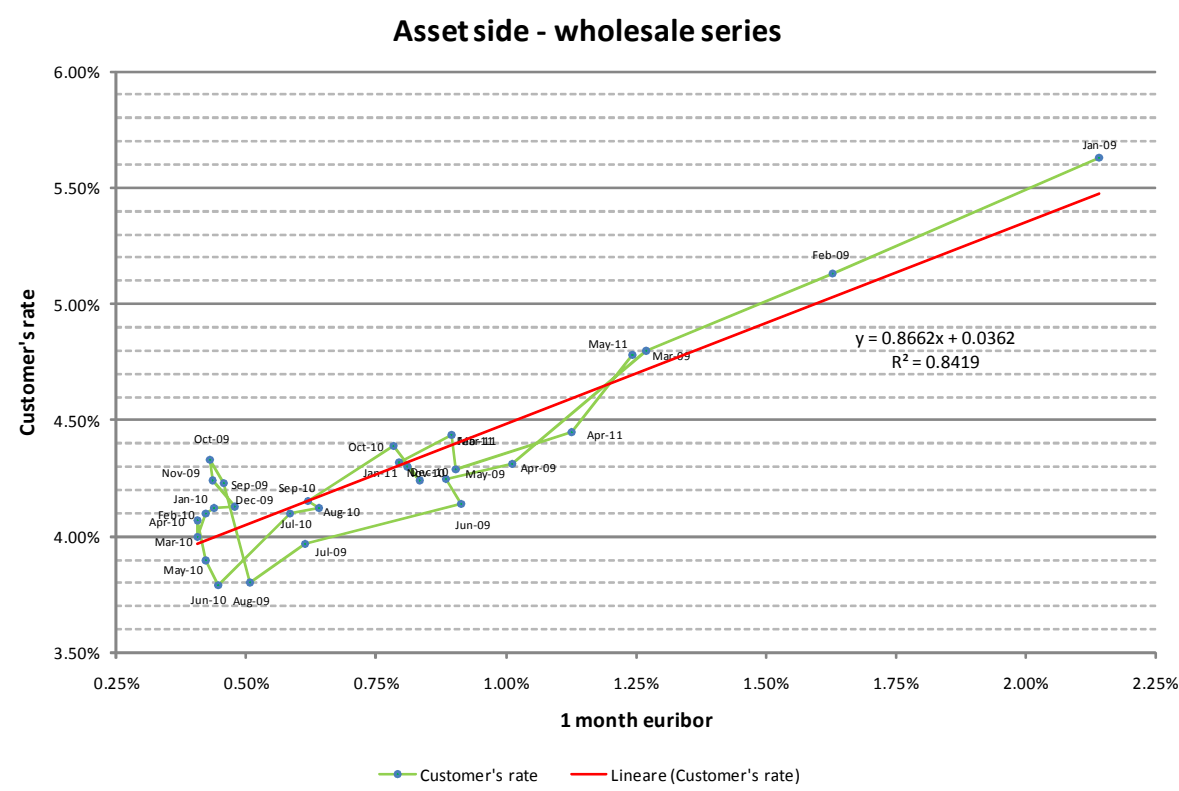

Upper limit: none

Figure 15: Correlation between Euribor and wholesale customer's rate (Upper limit: none)

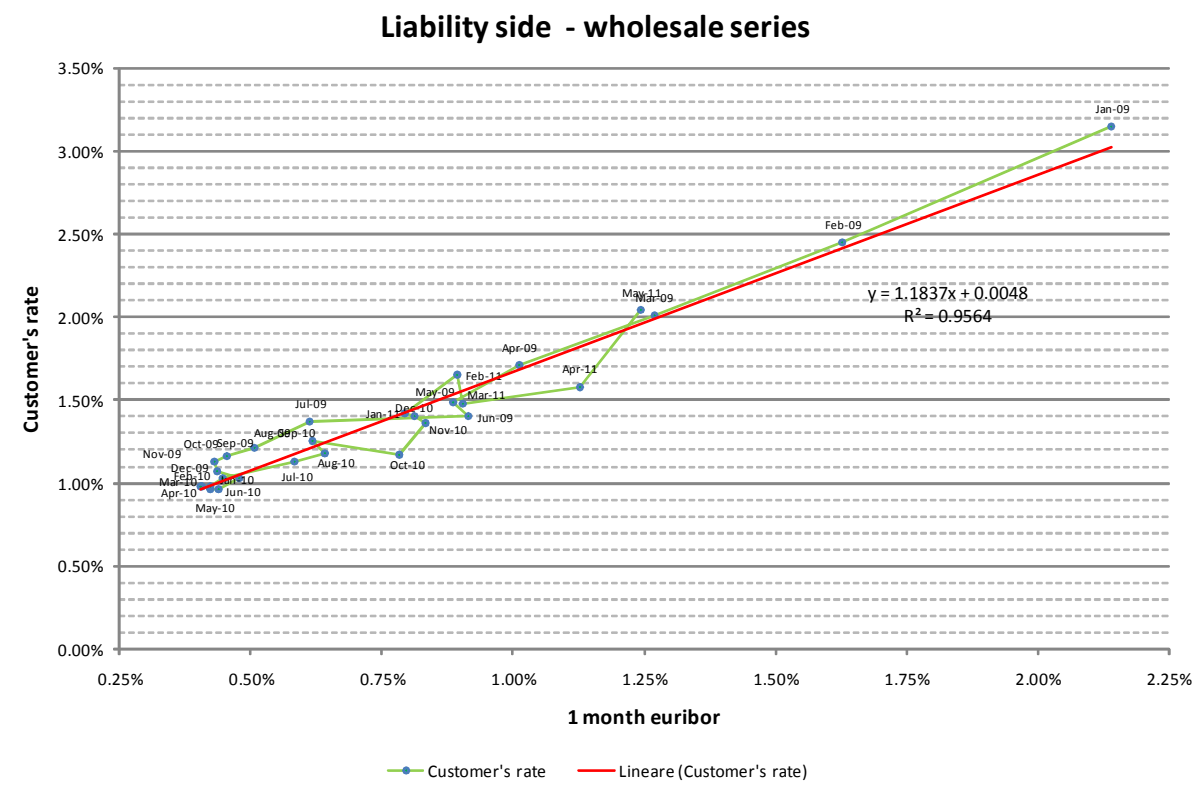

Upper limit: none

Figure 16: Correlation between Euribor and wholesale customer's rate (Upper limit: none) 


\subsection{The new model impact on the risk indicators}

The parameters used to measure the impact of the new methodology on risk indicators are summarized in the following table. The first five columns refer to ECM parameters, and in addition, the core percentage used in the volumes model is represented in the last one column.

\begin{tabular}{|c|c|c|c|c|c|c|c|}
\multirow{2}{*}{\begin{tabular}{c} 
Balance sheet side \\
\cline { 2 - 8 }
\end{tabular}} & Series & ALFA & \multicolumn{2}{c}{ BETA } & GAMMA PLUS GAMMA MINUS & THETA & $\%$ CORE \\
\hline Asset & Retail & $6.675 \%$ & 0.782 & 0.704 & 0.704 & -0.468126 & $96.448 \%$ \\
\hline Asset & Retail & $0.129 \%$ & 0.553 & - & 0.371 & -0.232517 & $94.272 \%$ \\
\hline Liability & Wholesale & $4.066 \%$ & 0.883 & 1.000 & 0.958 & -0.387386 & $97.070 \%$ \\
\hline Liability & Wholesale & $0.141 \%$ & 0.967 & - & 0.841 & -0.393967 & $91.841 \%$ \\
\hline
\end{tabular}

Figure 17: Applied parameters (ECM e volumes)

In case of instantaneous and parallel +100 bps shock, the effect of the new modeling on earnings is important. In Veneto Banca, we estimate a reduction in profits resulting from demand items of 14.18 million, compared with 10.45 of the old methodology. If we consider the overall effect on earnings, it results that the bank gains 13.9 million when rates upward (actual model), instead of 10.2 (new modelization).

\begin{tabular}{|c|c|c|c|c|c|c|c|c|}
\hline \multirow[b]{2}{*}{ Balance sheet } & \multicolumn{3}{|c|}{ ACTUAL MODEL } & \multicolumn{3}{|c|}{ NEW MODEL } & \multicolumn{2}{|c|}{ GAP } \\
\hline & Outstanding & $\begin{array}{l}\text { Delta } \\
\text { Earnings }\end{array}$ & Beta & Outstanding & $\begin{array}{l}\text { Delta } \\
\text { Earnings }\end{array}$ & Beta* & Outstanding & $\begin{array}{l}\text { Delta } \\
\text { Earnings }\end{array}$ \\
\hline \multicolumn{9}{|l|}{ ASSET } \\
\hline At sight modelization & $5,025.1$ & 39.2 & 0.75 & $4,424.4$ & 39.1 & 0.78 & -600.8 & -0.1 \\
\hline At sight items (no model.) & 853.8 & 8.5 & 1 & $1,454.6$ & 14.5 & 1 & 600.8 & 6.0 \\
\hline of which intercompany & 593.6 & & & 593.6 & & & & \\
\hline of which istitutional & 260.3 & & & 861.1 & & & & \\
\hline Other maturity items & $16,803.3$ & 130.6 & & $16,803.3$ & 130.6 & & & \\
\hline Modelization coverage (\%) & $85.5 \%$ & & & $75.3 \%$ & & & & \\
\hline Total - Asset & $22,682.3$ & 178.3 & & $22,682.3$ & 184.2 & & & 5.9 \\
\hline \multicolumn{9}{|l|}{ LIABILITY } \\
\hline At sight modelization & $-6,658.0$ & -33.9 & 0.46 & $-5,493.3$ & -31.9 & 0.70 & $1,164.7$ & 2.0 \\
\hline At sight items (no model.) & $-2,432.0$ & -24.3 & 1 & $-3,596.7$ & -36.0 & 1 & $-1,164.7$ & -11.6 \\
\hline of which intercompany & -102.6 & & & -102.6 & & & & \\
\hline of which istitutional & $-2,329.4$ & & & $-3,494.1$ & & & & \\
\hline Other maturity items & $31,786.6$ & -106.2 & & $31,786.6$ & -106.2 & & & \\
\hline Modelization coverage (\%) & $73.2 \%$ & & & $60.4 \%$ & & & & \\
\hline Total - Liability & $-22,696.6$ & -164.4 & & $-22,696.6$ & -174.1 & & & -9.7 \\
\hline TOTAL & -14.3 & 13.9 & & -14.3 & 10.2 & & & -3.7 \\
\hline
\end{tabular}

Figure 18: Impact on Earnings 
We can see the same effect on the change in economic value. In view of the same shocks, between the old and the new method there is a delta of 39.15 million. If we consider the overall position, with the new methodology the bank looses 57.3 million, instead of 18.3 .

\begin{tabular}{|c|c|c|c|c|c|c|c|c|}
\hline \multirow[b]{2}{*}{ Balance sheet } & \multicolumn{3}{|c|}{ ACTUAL MODEL } & \multicolumn{3}{|c|}{ NEW MODEL } & \multicolumn{2}{|c|}{ GAP } \\
\hline & Outstanding & Delta Value & Beta & Outstanding & $\begin{array}{l}\text { Delta } \\
\text { Value }\end{array}$ & Beta* & Outstanding & $\begin{array}{l}\text { Delta } \\
\text { Value }\end{array}$ \\
\hline ASSET & & & & & & & & \\
\hline At sight modelization & $5,025.1$ & -46.6 & 0.75 & $4,424.4$ & -43.2 & 0.78 & -600.8 & 3.4 \\
\hline At sight items (no model.) & 853.8 & 0.0 & 1 & $1,454.6$ & 0.0 & 1 & 600.8 & 0.0 \\
\hline of which intercompany & 593.6 & & & 593.6 & & & & \\
\hline of which istitutional & 260.3 & & & 861.1 & & & & \\
\hline Other maturity items & $16,803.3$ & -125.7 & & $16,803.3$ & -125.7 & & & \\
\hline Modelization coverage (\%) & $85.5 \%$ & & & $75.3 \%$ & & & & \\
\hline Total-Asset & $5,879.0$ & -172.3 & & $5,879.0$ & -169.0 & & & 3.3 \\
\hline LIABILITY & & & & & & & & \\
\hline At sight modelization & $-6,658.0$ & 101.3 & 0.46 & $-5,493.3$ & 58.8 & 0.70 & $1,164.7$ & -42.5 \\
\hline At sight items (no model.) & $-2,432.0$ & 0.1 & 1 & $-3,596.7$ & 0.1 & & $-1,164.7$ & 0.0 \\
\hline of which intercompany & -102.6 & & & -102.6 & & & & \\
\hline of which istitutional & $-2,329.4$ & & & $-3,494.1$ & & & & \\
\hline Other maturity items & $31,786.6$ & 52.8 & & $31,786.6$ & 52.8 & & & \\
\hline Modelization coverage (\%) & $73.2 \%$ & & & $60.4 \%$ & & & & \\
\hline Total - Liability & $-9,090.0$ & 154.1 & & $-9,090.0$ & 111.6 & & & -42.5 \\
\hline TOTAL & $-3,211.0$ & -18.2 & & $-3,211.0$ & -57.3 & & & -39.1 \\
\hline
\end{tabular}

Figure 19: Impact on Economic Value

Looking at Figure 19, we note that the beta of liabilities is the element that affects the results. In conclusion, the capital absorbed for interest rate risk protection with the methodology actually in use is far below what it should be if we considered the combined effect of the concentration risk, credit and interest rate.

\section{Conclusions}

The paper aims to demonstrate that wiser uses of econometrics tools can be more effective than the adoption of bulkier instruments in detecting banking risk. The real next strategic innovation in this field will be more concerned with methodologies fixing communication bugs inside the banking organization. This is because the corporate risk is portfolio of specific risks mixed with the ability of the organization to react to stressing changes to specific sources of risk. Increasing decision making efficacy will increase banking reaction and reduce real exposure.

The liquidity risk is no more an exception. Its impact is to be assessed according to the entire banking system, particularly for possible reaction in credit risk premia. Strategic decisions and commercial policies defined at corporate level can unexpectedly bias banking reaction. Complex econometric solutions may generate information asymmetries (i.e. an inflating information risk) between decision makers and the technical departments deputed to its treatment. Regulators 
should pay more attention to the methods to be used for assessing risk, since the effect could be more effective to the stability of the financial system.

The paper demonstrate the huge contribution that a wiser use of risk detection tecnologies may give to the banking organization. Using the real experience emerging from a pilot project run by Veneto Banca Group inside the Master in Strategic Innovation of $\mathrm{Ca}^{\prime}$ Foscari University. The emerging solution depicts a possible benchmark to carry on the liquidity risk detection even in banks greater than the group proposing it. Regulators could suggest it to reduce contagion effects but Banks could adapt it in order to increase their return-to-risk ratio.

\section{References}

A. Kanagala, M. Sahni, S. Sharma, B. Gou, J. Yu, "A probabilistic approach of Hirschman-Herfindahl Index $(\mathrm{HHI})$ to determine possibility of market power acquisition" - Power Systems Conference and Exposition, 2004

Basel Committee on Banking Supervision, "Basel II: International Convergence of Capital Measurement and Capital Standards - A revised framework" - Bank for International Settlements, June 2004

Basel Committee on Banking Supervision, "Basel III - International frame work for liquidity risk measurement, standards and monitoring" - Bank for International Settlements, December 2010

Basel Committee on Banking Supervision, "Principles For The Management And Supervision Of Interest Rate Risk" - Bank for International Settlements, January 2001

Basel Committee on Banking Supervision, "Principles for the Management and Supervision of Interest Rate Risk" - Bank for International Settlements, July 2004

Basel Committee on Banking Supervision, "Range of practices and issues in economic capital modelling - consultative paper" - Bank for International Settlements, August 2008

Comptroller's Handbook, "Interest Rate Risk" - Comptroller of The Currency Administrator of National Banks, Narrative June 1997 and Procedures March 1998

David M. Wright e James V. Houpt, Leeto Tlou e Jonathan Hacker, "An analysis of commercial bank exposure to interest rate risk"- Federal Reserve Bulletin, February 1996

Donald R. Fraser, Jeff Madura and Robert A. Weigand, "Sources of Bank Interest rate risk" - The financial review 37 (2002) 351 - 368 
Giovanni dell'Ariccia and Robert Marquez, "Risk and the Corporate Structure of Banks" - Journal of finance, Vol. LXV, $n^{\circ} 3$. June 2010

J. Duan, C.W. Sealey e Y. Yan, "Managing banks' duration gaps when interest rates are stochastic and equity has limited liability" - International Review of Economics and Finance, ${ }^{\circ} 8,1999$

James H. Stock and Mark W. Watson, "Introduction to econometrics" - Pearson Education, July 2005

Jeff Madura e Emilio R. Zarruk, "Bank exposure to interest rate risk: a global perspective" - The Journal of Financial Research, Vol. XVIII n¹, 1995

Jose A. Lopez, "Supervision interest rate risk management" - FRBSF Economic Letter, n²004-26, September 17, 2004

Mary E. Barth, Leslie D. Hodder e Stephen R. Stubben, "Fair value accounting for liabilities and own credit risk" - The Accounting Review, Vol. 83, n³, 2008

Oliver Entrop, Marco Wilkens e Alexander Zeisler, "Quantify the interest rate risk of banks" - European Financial Management, Vol. 15, n5, 2009

Piergiorgio Alessandri and Mathias Drehmann, "An economic capital model integrating credit and interest rate risk in the banking book" - ECB Working Paper no. 1041, April 2009

Piergiorgio Alessandri e Mathias Drehmann, "An economic capital model integrating credit and interest rate risk in the banking book" - Bank of England, Summary of working paper $n^{\circ} 388$, June 2010

Robert F. Engle and C. W. J. Granger, "Co-Integration and Error Correction: Representation, Estimation and Testing" - Econometrica, Vol. 55, No. 2, 251 276, March 1987

Weitzu Chen, Chi-Chun Liu e Stephen G. Ryan, "Characteristics of securizations that determine Issuers' retention of the risk of the securitized assets" - The Accounting Review, Vol. 83 n 5, 2008 